\title{
Gambaran Pola Bakteri dan Kepekaan Antibiotik pada Pasien Rawat Inap dengan Pneumonia di Rumah Sakit Paru dr. M. Goenawan Partowidigdo
}

\author{
Theresia Ervina ${ }^{1}$, Ade Dharmawan ${ }^{2}$, Elisabeth D Harahap ${ }^{2}$, Henny Tannady $\operatorname{Tan}^{3}$, Rini Latifah ${ }^{4}$ \\ ${ }^{1}$ Fakultas Kedokteran dan Ilmu Kesehatan, Universitas Kristen Krida Wacana, Jakarta, Indonesia \\ ${ }^{2}$ Departemen Mikrobiologi, Fakultas Kedokteran dan Ilmu Kesehatan, Universitas Kristen Krida \\ Wacana, Jakarta, Indonesia \\ ${ }^{3}$ Departemen Penyakit Dalam, Fakultas Kedokteran dan Ilmu Kesehatan, Universitas Kristen Krida \\ Wacana, Jakarta, Indonesia \\ ${ }^{4}$ RS Paru dr. M. Goenawan Partowidigdo, Bogor, Indonesia \\ Alamat Korespondensi: ade.dharmawan@ukrida.ac.id
}

\begin{abstract}
Abstrak
Prevalensi pneumonia menurut Riset Kesehatan Dasar Indonesia pada tahun 2018 yaitu sebesar $2 \%$. Streptococcus pneumoniae (pneumococcus) adalah patogen paling umum penyebab pneumonia. Penggunaan antibiotik yang berlebihan dan tidak tepat untuk terapi empiris sering menimbulkan resistensi antibiotik. Penelitian ini bertujuan untuk mengetahui pola bakteri dan penggunaan antibiotik terhadap bakteri penyebab pneumonia. Studi dilakukan dengan pendekatan cross-sectional dengan metode deskriptif. Sampel penelitian adalah rekam medis dari pasien terdiagnosis pneumonia yang dirawat inap di Rumah Sakit Paru dr. M. Goenawan Partowidigdo selama periode Januari-Juni 2019. Sampel ditetapkan secara total population sampling, dimana sebanyak 74 orang memenuhi kriteria inklusi. Didapatkan pola bakteri penyebab pneumonia didominasi oleh bakteri gram negatif. Dari hasil uji kepekaan antibiotik pada bakteri gram positif, didapatkan antibiotik yang memiliki tingkat sensitivitas di atas $70 \%$ adalah linezolid, nitrofurantoin, teicoplanin, dan vancomycin. Sedangkan, pada gram negatif adalah amikacin, gentamicin, imipenem, meropenem, dan piperacillin-tazobactam.
\end{abstract}

Kata Kunci: kepekaan antibiotik, pneumonia, pola bakteri

\section{Overview of Bacterial Patterns and Antibiotic Sensitivity among Inpatients with Pneumonia at dr. M. Goenawan Partowidigdo Lung Hospital}

\begin{abstract}
The prevalence of pneumonia according to Indonesia Basic Health Research in 2018 was 2\%. Streptococcus pneumoniae (pneumococcus) is the most common pathogen causing pneumonia. Eccessive and inappropriate use of antibiotics during empirical therapy causes antibiotic resistance. This study aimed to evaluate bacterial patterns and antibiotic sensitivity among inpatients with pneumonia. This study was a cross sectional descriptive study using secondary data from medical records in dr. M. Goenawan Partowidigdo Lung Hospital between January - June 2019. Samples were taken with a total sampling approach, thus 74 subjects all of whom were inpatients with pneumonia were included in the study. Results showed that the most common cause of pneumonia was gram-negative bacteria. Antibiotic sensitivity tests showed antibiotics with sensitivity level of more than $70 \%$ for gram-positive bacteria were linezolid, nitrofuranton, teicoplanin, and vancomycin, while for gram-negative bacteria were amikacin, gentamicin, imipenem, meropenem, and piperacillin-tazobactam.
\end{abstract}

Keywords: antibiotic sensitivity, bacterial pattern, pneumonia 


\section{Pendahuluan}

Pneumonia merupakan peradangan akut atau infeksi yang terjadi pada parenkim paru, dapat disebabkan oleh bakteri, virus, jamur, ataupun parasit. Pneumonia dapat menyerang siapa saja, baik anak maupun usia dewasa. ${ }^{1,2}$ Pneumonia merupakan penyakit infeksi tersering yang menyebabkan kematian pada anak-anak usia kurang dari 5 tahun di seluruh dunia, dengan perkiraan angka kematian mencapai 879.000 anak pada tahun 2016. ${ }^{3}$ Berdasarkan data WHO angka kematian pneumonia mencapai $16 \%$ dari seluruh penyebab kematian pada anak usia kurang dari 5 tahun. ${ }^{4}$

Pada tahun 2014, Pneumonia merupakan penyebab kematian keenam di Amerika Serikat menurut Pusat Statistik Kesehatan Nasional. ${ }^{5}$ Pneumonia adalah penyebab satu-satunya infeksi terbesar pada anak-anak di seluruh dunia. Pada 2017, tercatat sebanyak 808.694 kematian anak di bawah usia lima tahun disebabkan oleh pneumonia. Hal ini merupakan $15 \%$ dari semua kematian anak di bawah usia lima tahun. ${ }^{6}$ Pada tahun 2018, menurut Riset Kesehatan Dasar prevalensi pneumonia mencapai $2 \%$. Prevalensi pneumonia balita di Indonesia adalah 2,1\%. Jika didasarkan umur, pneumonia banyak terjadi pada kelompok umur kurang dari 4 tahun yaitu sebesar $4,2 \%$. Pneumonia juga meningkat pada umur 45-54 tahun dan makin meningkat pada usia selanjutnya. ${ }^{7}$

Pneumonia dapat terjadi di komunitas atau di lingkungan rumah sakit, dan dapat ditularkan melalui aspirasi atau inhalasi mikroorganisme patogen. Penting untuk mengetahui mikroorganisme patogen dalam etiologi infeksi pneumonia untuk pertimbangan manajemen klinis dan terapi yang memadai bagi pasien. ${ }^{8}$

Secara global, Streptococcus pneumoniae (pneumococcus) adalah patogen paling sering yang menyebabkan pneumonia. Pneumococcus merupakan salah satu bakteri yang menjadi perhatian internasional terkait dengan resistensi antibiotik global yang diterbitkan oleh Organisasi Kesehatan Dunia (WHO) pada tahun 2014. ${ }^{6}$ Berbagai patogen yang diperoleh baik dari pasien atau dari lingkungan rumah sakit dapat menyebabkan pneumonia nosokomial. Namun, bakteri Gram-negatif lebih sering menjadi patogen penyebab dibandingkan dengan bakteri Grampositif. ${ }^{9}$ Penyebab pneumonia utamanya adalah bakteri, walaupun virus, jamur, dan berbagai senyawa kimia maupun partikel lainnya juga dapat menjadi penyebabnya. Penyakit pneumonia dapat terjadi pada semua usia, namun manifestasi klinis terparah terjadi pada anak, orang tua, dan penderita penyakit kronis. ${ }^{9}$

Tingginya angka prevalensi pneumonia baik di dunia maupun di Indonesia berbanding lurus dengan angka mortalitas. Dalam praktek klinis patogen penyebab seringkali tidak diketahui, dan kebanyakan pasien diberikan terapi antibiotik secara empirik. ${ }^{10}$ Berdasarkan studi yang dilakukan oleh tim Fakultas Kedokteran dan Fakultas Farmasi Universitas Gadjah Mada pada tahun 2014 di bangsal anak RS dr. R. Soetrasno Rembang diketahui sebanyak $49,7 \%$ penggunaannya rasional dan sebanyak 50,3\% tidak rasional. ${ }^{11}$ Dampak negatif dari penggunaan antibiotik yang tidak rasional adalah munculnya bakteri-bakteri resisten antibiotik. Resistensi ini menyebabkan kegagalan terapi sehingga kondisi pasien menjadi semakin buruk bahkan hingga sampai kematian. ${ }^{12}$

Dalam tatalaksana pneumonia sangat penting untuk mengetahui hasil kultur mikroorganisme penyebab. Pneumonia yang disebabkan oleh virus tidak diperlukan pemberian antibiotik, namun terkadang antibiotik digunakan jika ada potensi untuk terjadinya infeksi sekunder, atau ketika tidak dapat dibedakan penyebabnya antara bakteri atau virus. Oleh karena itu pemberian antibiotik empirik tetap digunakan pada pasien pneumonia yang belum diketahui etiologinya. Acuan pemberian antibiotik empirik berdasarkan patogen yang paling sering menyebabkan pneumonia di daerah setempat sesuai pola bakteri yang dimiliki rumah sakit masing-masing. ${ }^{13}$ Tujuan penelitian ini adalah untuk mengetahui pola bakteri dan penggunaan antibiotik terhadap bakteri penyebab pneumonia di Rumah Sakit Paru dr. M. Goenawan Partowidigdo Periode Januari - Juni 2019.

\section{Metodologi}

Desain penelitian ini adalah studi deskriptif, dengan pendekatan cross-sectional. Penelitian dilakukan dengan mengumpulkan data rekam medik pasien rawat inap dengan diagnosa pneumonia di Rumah Sakit Paru dr. M. Goenawan Partowidigdo, Cisarua, dalam kurun waktu September - November 2019.

Kriteria inklusi penelitian ini adalah rekam medis dari semua pasien pneumonia $\geq 18$ tahun yang dirawat inap di Rumah Sakit Paru dr. M. Goenawan Partowidigdo, Cisarua pada periode Januari - Juni 2019, dan yang telah dilakukan kultur bakteri dengan kualitas sputum baik (jumlah epitel < 10/LPK atau jumlah leukosit 10x lebih banyak dari jumlah epitel) dan hasilnya positif. Kriteria eksklusi yaitu rekam medis dari pasien Pneumonia usia 
dibawah 18 tahun, data rekam medik yang tidak lengkap.

Metode sampling dalam penelitian ini menggunakan teknik total sampling. Pada penelitian ini jumlah subjek pasien rawat inap yang terdiagnosis pneumonia mencapai 578 pasien baik infeksi primer maupun infeksi sekunder, dengan 74 pasien yang telah memenuhi kriteria inklusi. Parameter yang diperiksa adalah data rekam medik mengenai pola bakteri dan kepekaannya terhadap suatu antibiotik pada pasien pneumonia dengan variabel terikat yaitu pola bakteri dan kepekaan antibiotik dan variabel bebas yaitu pneumonia.

\section{Hasil}

\section{Karakteristik Responden}

Berdasarkan data rekam medis yang sesuai dengan kriteria inklusi, didapatkan jumlah pasien laki-laki 43 pasien dan perempuan 31 pasien. Hasil ini sesuai dengan beberapa studi, salah satunya yang dilakukan oleh Weber dan Handy (2010) yang menyatakan bahwa proporsi laki-laki dalam penyakit sistem pernapasan lebih besar daripada perempuan. ${ }^{14}$ Penelitian lain yang sesuai yaitu pada data Kemenkes RI (2018) yang

\section{Hasil Identifikasi Bakteri}

Pada data hasil kultur subjek yang masuk dalam kriteria inklusi didapatkan 74 patogen dari menyatakan bahwa prevalensi pneumonia pada laki-laki lebih tinggi dibanding pada perempuan. ${ }^{7}$

Berdasarkan rekam medis, juga ditemukan bahwa pasien pneumonia didominasi pasien dengan usia di atas 45 tahun. Hal ini sesuai dengan hasil Riskesdas pada tahun 2013 yang menjelaskan bahwa prevalensi pneumonia mulai meningkat pada usia 45-54 tahun dan terus bertambah pada kelompok umur berikutnya. Hal ini terjadi karena daya tahan yang semakin menurun seiring bertambahnya usia. ${ }^{15}$

\section{Hasil Persentase Kultur}

Pada Rumah Sakit Paru dr. M. Goenawan Partowidigdo, jenis spesimen yang digunakan pada pemeriksaan kultur adalah spesimen sputum. Penilaian kualitas spesimen dilakukan dengan pewarnaan gram, kemudian dilanjutkan dengan identifikasi bakteri dengan uji biakan dan uji kepekaan yang dilakukan dengan menggunakan teknik Minimum Inhibitory Concentration (MIC) yang dikerjakan dalam alat kultur Phoenix ${ }^{\circledR}$.

Dari 578 pasien rawat inap pneumonia yang dijumpai di RS dr. M. Goenawan Partowidigdo, hanya 122 pasien, atau $17 \%$ dari total pasien yang melakukan kultur sputum karena keterbatasan finansial pasien.

74 pasien pneumonia, yang terdiri dari bakteri gram positif dan bakteri gram negatif, seperti ditunjukkan pada tabel 1 di bawah ini.

Tabel 1. Gambaran Bakteri Penyebab Pneumonia

\begin{tabular}{clcc}
\hline No & \multicolumn{1}{c}{ Mikroorganisme } & Jumlah & \% \\
\hline $\mathbf{1}$ & Acinetobacter baumannii & 11 & 14,86 \\
$\mathbf{2}$ & Pseudomonas aeruginosa & 9 & 12,16 \\
$\mathbf{3}$ & Staphylococcus haemolyticus & 8 & 10,81 \\
$\mathbf{4}$ & Klebsiella pneumoniae & 7 & 9,46 \\
$\mathbf{5}$ & Staphylococcus aureus & 6 & 8,11 \\
$\mathbf{6}$ & Escherichia coli & 4 & 5,41 \\
$\mathbf{7}$ & Enterobacter cloacae & 3 & 4,05 \\
$\mathbf{8}$ & Enterococcus faecalis & 3 & 4,05 \\
$\mathbf{9}$ & Stenotrophomonas maltophilia & 3 & 4,05 \\
$\mathbf{1 0}$ & Staphylococcus epidermidis & 3 & 4,05 \\
$\mathbf{1 1}$ & Serratia marcescens & 3 & 4,05 \\
$\mathbf{1 2}$ & Lain-lain & 14 & 18,92 \\
& Total & 74 & 100 \\
\hline
\end{tabular}


Hasil kultur bakteri dengan metode deteksi uji biokima yang menggunakan Phoenix ${ }^{\circledR}$ menunjukkan ada sebelas bakteri yang paling sering menjadi patogen penyebab pneumonia. Bakteri lain yang juga ditemukan sebagai penyebab adalah Aeromonas caviae, Bacillus sp., Enterobacter aerogenes, Kluyvera ascorbata,

\section{Hasil Uji Kepekaan Antibiotik}

Uji kepekaan antibiotik di Rumah Sakit Paru dr. M. Goenawan Partowidigdo menggunakan teknik yang sama dengan teknik kultur bakterinya
Klebsiella oxytoca, Klebsiella pneumoniae ss. ozaenae, Pseudomonas cepacia, Pseudomonas pickettii, Pseudomonas putida, Providencia rettgeri, Staphylococcus carnosus, Staphylococcus hominis, Staphylococcus lugdunensis, Stomatococcus mucilaginosus yang masing-masing berjumlah satu mikroorganisme. yaitu dengan teknik MIC yang dikerjakan oleh alat kultur Phoenix. Uji kepekaan ini dibagi menjadi dua panel, yaitu panel untuk bakteri gram positif dan bakteri gram negatif. Di dapatkan hasil masing-masing panel seperti yang ditunjukkan pada tabel 2 dan 3.

Tabel 2. Hasil Uji Kepekaan Antibiotik Bakteri Gram Positif

\begin{tabular}{|c|c|c|c|c|c|c|c|c|c|c|c|c|c|c|c|c|c|c|}
\hline No. & $\begin{array}{c}\text { Bakteri Gram } \\
\text { Positif }\end{array}$ & AMX & $\mathrm{AM}$ & $\mathrm{C}$ & CIP & DA & $\mathrm{E}$ & GEN & LVX & LZD & MXF & NIF & OX & PEN & TEC & TE & SXT & VA \\
\hline 1. & S. haemol. & $\begin{array}{c}0 \\
(8)\end{array}$ & $\begin{array}{c}0 \\
(8)\end{array}$ & $\begin{array}{l}57 \\
(7)\end{array}$ & $\begin{array}{c}0 \\
(8)\end{array}$ & $\begin{array}{c}0 \\
(4)\end{array}$ & $\begin{array}{c}0 \\
(7)\end{array}$ & $\begin{array}{c}0 \\
(8)\end{array}$ & $\begin{array}{c}0 \\
(8)\end{array}$ & $\begin{array}{l}100 \\
(8)\end{array}$ & $\begin{array}{l}50 \\
(8)\end{array}$ & $\begin{array}{l}83 \\
(6)\end{array}$ & $\begin{array}{c}0 \\
(6)\end{array}$ & $\begin{array}{c}0 \\
(5)\end{array}$ & $\begin{array}{l}71 \\
(7)\end{array}$ & $\begin{array}{l}50 \\
(2)\end{array}$ & $\begin{array}{l}75 \\
(8)\end{array}$ & $\begin{array}{l}88 \\
(8)\end{array}$ \\
\hline 2. & S. aureus & $\begin{array}{l}20 \\
(5)\end{array}$ & $\begin{array}{c}0 \\
(5)\end{array}$ & $\begin{array}{l}80 \\
(5)\end{array}$ & $\begin{array}{l}67 \\
(6)\end{array}$ & $\begin{array}{l}75 \\
(4)\end{array}$ & $\begin{array}{l}50 \\
(6)\end{array}$ & $\begin{array}{l}50 \\
(6)\end{array}$ & $\begin{array}{l}67 \\
(6)\end{array}$ & $\begin{array}{l}100 \\
(6)\end{array}$ & $\begin{array}{l}67 \\
(6)\end{array}$ & $\begin{array}{l}100 \\
(5)\end{array}$ & $\begin{array}{l}20 \\
(5)\end{array}$ & $\begin{array}{c}0 \\
(5)\end{array}$ & $\begin{array}{l}100 \\
(4)\end{array}$ & $\begin{array}{l}100 \\
(1)\end{array}$ & $\begin{array}{l}100 \\
(6)\end{array}$ & $\begin{array}{l}100 \\
(6)\end{array}$ \\
\hline 3. & S. epidermidis & $\begin{array}{l}33 \\
(3)\end{array}$ & $\begin{array}{c}0 \\
(3)\end{array}$ & $\begin{array}{l}33 \\
(3)\end{array}$ & $\begin{array}{l}33 \\
(3)\end{array}$ & $\begin{array}{l}100 \\
(2)\end{array}$ & $\begin{array}{l}67 \\
(3)\end{array}$ & $\begin{array}{l}33 \\
(3)\end{array}$ & $\begin{array}{l}67 \\
(3)\end{array}$ & $\begin{array}{l}100 \\
(3)\end{array}$ & $\begin{array}{l}100 \\
(3)\end{array}$ & $\begin{array}{l}100 \\
(2)\end{array}$ & $\begin{array}{l}33 \\
(3)\end{array}$ & $\begin{array}{c}0 \\
(3)\end{array}$ & $\begin{array}{l}100 \\
(3)\end{array}$ & $\begin{array}{c}0 \\
(0)\end{array}$ & $\begin{array}{l}33 \\
(3)\end{array}$ & $\begin{array}{l}100 \\
(3)\end{array}$ \\
\hline 4. & E. faecalis & $\begin{array}{c}0 \\
(0)\end{array}$ & $\begin{array}{l}67 \\
(3)\end{array}$ & $\begin{array}{l}33 \\
(3)\end{array}$ & $\begin{array}{c}0 \\
(3)\end{array}$ & $\begin{array}{c}0 \\
(3)\end{array}$ & $\begin{array}{c}0 \\
(3)\end{array}$ & $\begin{array}{c}0 \\
(3)\end{array}$ & $\begin{array}{c}0 \\
(3)\end{array}$ & $\begin{array}{l}67 \\
(3)\end{array}$ & $\begin{array}{c}0 \\
(3)\end{array}$ & $\begin{array}{l}100 \\
(3)\end{array}$ & $\begin{array}{c}0 \\
(0)\end{array}$ & $\begin{array}{c}0 \\
(2)\end{array}$ & $\begin{array}{l}100 \\
(3)\end{array}$ & $\begin{array}{c}0 \\
(0)\end{array}$ & $\begin{array}{c}0 \\
(2)\end{array}$ & $\begin{array}{l}100 \\
(2)\end{array}$ \\
\hline
\end{tabular}

Tabel 3. Hasil Uji Kepekaan Antibiotik Bakteri Gram Negatif

\begin{tabular}{|c|c|c|c|c|c|c|c|c|c|c|c|c|c|c|c|c|c|c|c|c|c|}
\hline No & $\begin{array}{c}\text { Bakteri Gram } \\
\text { Negatif }\end{array}$ & AMC & MX & $\mathbf{A M}$ & AM & AZM & ATM & CRO & FEP & CTX & CAZ & $\mathbf{C}$ & CIP & GEN & IPM & LVX & MEM & IXF & TZP & TE & SXT \\
\hline 1 & A. baumannii & $\begin{array}{c}91 \\
(11)\end{array}$ & $\begin{array}{c}0 \\
(10)\end{array}$ & $\begin{array}{c}0 \\
(10)\end{array}$ & $\begin{array}{c}91 \\
(11)\end{array}$ & $\begin{array}{c}0 \\
(2)\end{array}$ & $\begin{array}{c}0 \\
(8)\end{array}$ & $\begin{array}{c}0 \\
(11)\end{array}$ & $\begin{array}{c}73 \\
(11)\end{array}$ & $\begin{array}{c}36 \\
(11)\end{array}$ & $\begin{array}{l}73 \\
(11)\end{array}$ & $\begin{array}{c}0 \\
(10)\end{array}$ & $\begin{array}{c}64 \\
(11)\end{array}$ & $\begin{array}{c}45 \\
(11)\end{array}$ & $\begin{array}{c}90 \\
(10)\end{array}$ & $\begin{array}{l}67 \\
(9)\end{array}$ & $\begin{array}{c}91 \\
(11)\end{array}$ & $\begin{array}{l}100 \\
(1)\end{array}$ & $\begin{array}{c}80 \\
(10)\end{array}$ & $\begin{array}{l}100 \\
(1)\end{array}$ & $\begin{array}{c}90 \\
(10)\end{array}$ \\
\hline 2 & P. aeruginosa & $\begin{array}{l}100 \\
(8)\end{array}$ & $\begin{array}{c}0 \\
(6)\end{array}$ & $\begin{array}{c}0 \\
(5)\end{array}$ & $\begin{array}{c}0 \\
(6)\end{array}$ & $\begin{array}{c}0 \\
(1)\end{array}$ & $\begin{array}{l}71 \\
(7)\end{array}$ & $\begin{array}{c}0 \\
(9)\end{array}$ & $\begin{array}{l}88 \\
(8)\end{array}$ & $\begin{array}{c}0 \\
(6)\end{array}$ & 75 & $\begin{array}{c}0 \\
(6)\end{array}$ & 88 & $\begin{array}{l}100 \\
(8)\end{array}$ & $\begin{array}{l}100 \\
(5)\end{array}$ & 80 & & $\begin{array}{c}0 \\
(0)\end{array}$ & $\begin{array}{l}100 \\
(7)\end{array}$ & $\begin{array}{c}0 \\
(0)\end{array}$ & $\begin{array}{c}0 \\
(6)\end{array}$ \\
\hline 3 & K. pnet & $\begin{array}{l}100 \\
(7)\end{array}$ & $\begin{array}{l}57 \\
(7)\end{array}$ & $\begin{array}{c}0 \\
(7)\end{array}$ & $\begin{array}{l}57 \\
(7)\end{array}$ & $\begin{array}{c}0 \\
(0)\end{array}$ & $\begin{array}{l}67 \\
(6)\end{array}$ & $\begin{array}{c}0 \\
(2)\end{array}$ & $\begin{array}{l}67 \\
(6)\end{array}$ & $\begin{array}{l}71 \\
(7)\end{array}$ & $\begin{array}{l}71 \\
(7)\end{array}$ & $\begin{array}{l}86 \\
(7)\end{array}$ & $\begin{array}{l}71 \\
(7)\end{array}$ & $\begin{array}{l}86 \\
(7)\end{array}$ & $\begin{array}{l}100 \\
(7)\end{array}$ & $\begin{array}{l}86 \\
(7)\end{array}$ & & $\begin{array}{l}71 \\
(7)\end{array}$ & $\begin{array}{l}71 \\
(7)\end{array}$ & $\begin{array}{c}0 \\
(0)\end{array}$ & $\begin{array}{l}43 \\
(7)\end{array}$ \\
\hline 4 & E. & $\begin{array}{l}100 \\
(4)\end{array}$ & $\begin{array}{c}0 \\
(3)\end{array}$ & $\begin{array}{c}0 \\
(4)\end{array}$ & $\begin{array}{c}0 \\
(4)\end{array}$ & $\begin{array}{c}0 \\
(0)\end{array}$ & $\begin{array}{l}25 \\
(4)\end{array}$ & $\begin{array}{c}0 \\
(3)\end{array}$ & $\begin{array}{l}25 \\
(4)\end{array}$ & $\begin{array}{l}25 \\
(4)\end{array}$ & $\begin{array}{l}25 \\
(4)\end{array}$ & $\begin{array}{l}67 \\
(3)\end{array}$ & $\begin{array}{l}25 \\
(4)\end{array}$ & $\begin{array}{l}50 \\
(4)\end{array}$ & $\begin{array}{l}100 \\
(3)\end{array}$ & $\begin{array}{c}0 \\
(3)\end{array}$ & & $\begin{array}{c}0 \\
\text { (3) }\end{array}$ & $\begin{array}{l}50 \\
(4)\end{array}$ & $\begin{array}{c}0 \\
(0)\end{array}$ & $\begin{array}{l}50 \\
(4)\end{array}$ \\
\hline 5 & E. $c$ & $\begin{array}{l}100 \\
(3)\end{array}$ & $\begin{array}{c}0 \\
(3)\end{array}$ & $\begin{array}{c}0 \\
(3)\end{array}$ & $\begin{array}{c}0 \\
(3)\end{array}$ & $\begin{array}{c}0 \\
(0)\end{array}$ & $\begin{array}{l}67 \\
(3)\end{array}$ & $\begin{array}{l}33 \\
(3)\end{array}$ & $\begin{array}{l}67 \\
(3)\end{array}$ & $\begin{array}{l}67 \\
(3)\end{array}$ & $\begin{array}{l}33 \\
(3)\end{array}$ & $\begin{array}{l}100 \\
(3)\end{array}$ & $\begin{array}{l}100 \\
(3)\end{array}$ & $\begin{array}{l}100 \\
(3)\end{array}$ & $\begin{array}{l}100 \\
(3)\end{array}$ & $\begin{array}{l}100 \\
(3)\end{array}$ & (3) & $\begin{array}{l}67 \\
(3)\end{array}$ & $\begin{array}{l}100 \\
(3)\end{array}$ & $\begin{array}{c}0 \\
(0)\end{array}$ & $\begin{array}{l}100 \\
(3)\end{array}$ \\
\hline 6 & S. maltophilia & $\begin{array}{c}0 \\
(2)\end{array}$ & $\begin{array}{c}0 \\
(2)\end{array}$ & $\begin{array}{c}0 \\
(1)\end{array}$ & $\begin{array}{c}0 \\
(2)\end{array}$ & $\begin{array}{c}0 \\
(0)\end{array}$ & $\begin{array}{c}0 \\
(2)\end{array}$ & $\begin{array}{c}0 \\
(2)\end{array}$ & $\begin{array}{c}0 \\
(0)\end{array}$ & $\begin{array}{c}0 \\
(2)\end{array}$ & $\begin{array}{c}0 \\
(2)\end{array}$ & $\begin{array}{l}50 \\
(2)\end{array}$ & $\begin{array}{c}0 \\
(0)\end{array}$ & $\begin{array}{c}0 \\
(2)\end{array}$ & $\begin{array}{c}0 \\
(2)\end{array}$ & $\begin{array}{c}0 \\
(2)\end{array}$ & $\begin{array}{c}0 \\
(2)\end{array}$ & $\begin{array}{c}0 \\
(0)\end{array}$ & $\begin{array}{c}0 \\
(2)\end{array}$ & $\begin{array}{c}0 \\
(1)\end{array}$ & $\begin{array}{l}67 \\
(3)\end{array}$ \\
\hline 7 & S. $m a$ & $\begin{array}{l}100 \\
(3)\end{array}$ & $\begin{array}{c}0 \\
(3)\end{array}$ & $\begin{array}{c}0 \\
(3)\end{array}$ & $\begin{array}{l}33 \\
(3)\end{array}$ & $\begin{array}{c}0 \\
(0)\end{array}$ & $\begin{array}{l}67 \\
(3)\end{array}$ & $\begin{array}{c}0 \\
(3) \\
\end{array}$ & $\begin{array}{l}67 \\
(3)\end{array}$ & $\begin{array}{l}67 \\
(3)\end{array}$ & $\begin{array}{l}67 \\
(3)\end{array}$ & $\begin{array}{c}0 \\
(3)\end{array}$ & $\begin{array}{l}67 \\
(3)\end{array}$ & $\begin{array}{l}100 \\
(3)\end{array}$ & $\begin{array}{l}67 \\
(3)\end{array}$ & $\begin{array}{l}100 \\
(3)\end{array}$ & $\begin{array}{l}100 \\
(3)\end{array}$ & $\begin{array}{l}100 \\
(3)\end{array}$ & $\begin{array}{l}100 \\
(3)\end{array}$ & $\begin{array}{c}0 \\
(0)\end{array}$ & $\begin{array}{l}67 \\
(3)\end{array}$ \\
\hline
\end{tabular}




\section{Keterangan:}

- Angka dibagian depan adalah persentase (\%) bakteri yang masih sensitif/peka terhadap antibiotik. Angka didalam tanda kurung adalah jumlah bakteri yang diujikan.

- AMX (Amoxicillin), AM (Ampicillin), C (Chloramphenicol), CIP (Ciprofloxacin), DA (Clindamycin), E (Erithromycin), Gen (Gentamycin), LVX (Levofloxacin), LZD (Linezolid), MXF (Moxifloxacin), NIF (Nitrofurantoin), OX (Oxacillin), PEN
(Penicillin), TEC (Teicoplanin), TE

(Tetracyclin), SXT (Sulfamethoxazole), VA

(Vancomycin), AMC (Amoxicillin-

Clavulanate), SAM (Ampicillin-Sulbactam), AZM (Azithromycin), ATM (Aztreonam), CRO (Ceftriaxone), FEP (Cefepime), CTX (Cefotaxime), CAZ (Ceftazidime), IPM (Imipenem), MEM (Meropenem), TZP (Piperacillin-Tazobactam)

Tabel 4. Persentase Sensitivitas Bakteri Gram Positif Terhadap Antibiotik

\begin{tabular}{|c|c|c|c|c|c|c|c|c|c|c|c|c|c|c|c|c|}
\hline & AMX & $\mathrm{AM}$ & $\mathrm{C}$ & CIP & $\mathrm{DA}$ & $\mathrm{E}$ & GEN & LVX & LZD & MXF & NIF & $\mathrm{OX}$ & PEN & TEC & $\mathrm{TE}$ & SXT VA \\
\hline $\begin{array}{l}\text { Bakteri } \\
\text { Gram } \\
\text { Positif }\end{array}$ & $13 \%$ & $11 \%$ & $56 \%$ & $25 \%$ & $39 \%$ & $26 \%$ & $20 \%$ & $30 \%$ & $95 \%$ & $55 \%$ & $94 \%$ & $14 \%$ & $0 \%$ & $88 \%$ & $67 \%$ & $68 \% 95 \%$ \\
\hline
\end{tabular}

Tabel 5. Persentase Sensitivitas Bakteri Gram Negatif Terhadap Antibiotik

AMCAMX AM SAM AZM ATM CRO FEP CTX CAZ C CIP GEN IPM LVX MEM MXF TZP TE SXT

\begin{tabular}{l}
$\begin{array}{l}\text { Bakteri } \\
\text { Gram } \\
\text { Negatif }\end{array}$ \\
\hline
\end{tabular}

\section{Pembahasan}

Hasil identifikasi pada penelitian ini menunjukkan bakteri gram negatif menduduki jumlah terbanyak sebagai penyebab pneumonia yaitu sebesar $66,2 \%$ dari total seluruh hasil kultur bakteri, yang terdiri dari Acinetobacter baumannii, Pseudomonas aeruginosa, Klebsiella pneumoniae, Escherichia coli, Enterobacter cloacae, Stenotrophomonas maltophilia, Serratia marcescens, Aeromonas caviae, Enterobacter aerogenes, Kluyvera ascorbata, Klebsiella oxytoca, Klebsiella pneumoniae ssp. ozaenae, Pseudomonas cepacia, Pseudomonas pickettii, Pseudomonas putida, Providencia rettgeri. Sedangkan, bakteri gram positif yang menjadi penyebab pneumonia yaitu sebesar 32,8\% yang terdiri dari Staphylococcus haemolyticus, Staphylococcus aureus, Staphylococcus epidermidis, Enterococcus faecalis, Bacillus sp., Staphylococcus carnosus, Staphylococcus hominis, Staphylococcus lugdunensis, Stomatococcus mucilaginosus. Beberapa bakteri yang didapatkan meskipun tidak umum sebagai penyebab pneumonia, namun juga dapat menjadi patogen penyebab pneumonia. Hasil penelitian ini sedikit berbeda dengan artikel penelitian yang dilakukan oleh Farida H, dkk. (2013), dan Dharmawan A, dkk. (2020) yang menyatakan bahwa bakteri penyebab tersering pneumonia adalah bakteri gram negatif, yaitu Klebsiella pneumoniae. Hal ini dapat disebabkan karena Indonesia merupakan negara berkembang yang biasanya memiliki sanitasi kurang baik, masyarakat yang sering mengonsumsi dan memasak menggunakan air yang terkontaminasi meningkatkan risiko penularan pneumonia. ${ }^{16,17}$

Dari hasil penelitian diperoleh bahwa terdapat tiga bakteri tersering penyebab pneumonia yaitu Acinetobacter baumannii, Pseudomonas aeruginosa, dan Staphylococcus haemolyticus (Tabel 1). Walaupun memiliki sedikit perbedaan, namun penelitian ini sesuai dengan penelitian yang dilakukan oleh Asadullah dkk. (2015) mengenai bakteri tersering penyebab pneumonia nosokomial dan didapatkan tiga bakteri tersering, yaitu Pseudomonas aeruginosa (24\%), diikuti Acinetobacter spp (16\%), dan 
Acinetobacter baumanii $(12 \%){ }^{15} \quad$ Bakteri Pseudomonas aeruginosa, Acinetobacter baumanii dan Stenotrophomonas maltophilia dikaitkan dengan infeksi nosokomial yang sering menjadi penyebab infeksi yang multi resisten. ${ }^{18}$ Hasil yang tidak jauh berbeda juga didapatkan dari penelitian yang dilakukan Kurniawan J dkk, (2015), tiga bakteri tersering yaitu Klebsiella $s p$ (47,54\%), diikuti Sreptococcus a hemolyticus (38,43\%), dan Staphylococcus aureus $(12,50 \%) .{ }^{19}$

Dari pengujian sensitivitas antibiotika menggunakan panel pedoman Clinical and Laboratory Standards Institute (CLSI). ${ }^{20}$ Total seluruh bakteri gram positif yang telah diuji dari spesimen sputum pneumonia, didapatkan bahwa terdapat beberapa antibiotik yang memiliki sensitivitas di atas $70 \%$ yaitu linezolid, nitrofurantoin, teicoplanin, dan vancomycin (Tabel 4). Sedangkan pada bakteri gram negatif, antibiotik yang memiliki sensitivitas di atas $70 \%$ yaitu amikacin, gentamicin, imipenem, meropenem, dan piperacillin-tazobactam (Tabel 5). Hal ini sesuai dengan guideline yang dikeluarkan oleh Infectious Diseases Society of America (IDSA) pada pasien HAP mengenai pemberian terapi empiris. Pada pasien rawat inap dengan pneumonia yang disebabkan oleh patogen gram positif sebaiknya diberikan terapi empiris antibiotik yang memiliki spektrum terhadap gram positif. Vancomycin dan Linezolid adalah antibiotik yang direkomendasikan sebagai terapi empiris Methicilin-Resistant Staphylococcus aureus (MRSA) dan pada penelitian ini didapatkan bahwa bakteri masih menunjukkan respon sensitif terhadap antibiotik tersebut.

Sedangkan, untuk pasien rawat inap pneumonia dengan kecurigaan terhadap bakteri gram negatif, sebaiknya diberikan terapi empiris terutama untuk Pseudomonas aeruginosa. Antibiotik tersebut antara lain piperacillintazobactam, cefepime, ceftazidime, aztreonam, meropenem, dan imipenem. Pada penelitian ini, didapatkan bahwa bakteri masih menunjukkan respon sensitif terhadap imipenem, meropenem, dan piperacillin-tazobactam. Terapi antibiotik kombinasi sebaiknya diberikan dari dua kelas yang berbeda. ${ }^{21}$

Pemilihan antibiotik untuk terapi sebaiknya diberikan berdasarkan penelitian yang telah dilakukan secara berkala oleh rumah sakit setempat mengenai pola bakteri dan pola kepekaan antibiotik. Hal ini dilakukan agar penggunaan regimen antibiotik empiris didasarkan pada distribusi patogen lokal dan kepekaan antibiotiknya pada daerah masingmasing.

\section{Simpulan}

Hasil penelitian ini menunjukkan bahwa jumlah kasus pneumonia pada laki-laki lebih banyak dibandingkan perempuan. Bakteri penyebab pneumonia didominasi oleh bakteri gram negatif dengan proporsi sebanyak $66,2 \%$ dan bakteri gram positif sebanyak 32,8\%. Tiga bakteri terbanyak penyebab pneumonia yaitu Acinetobacter baumanii, Pseudomonas aeruginosa, dan Staphylococcus haemolyticus. Hasil uji kepekaan antibiotik bakteri gram positif pada penelitian ini yang memiliki sensitivitas di atas $70 \%$ adalah linezolid, nitrofurantoin, teicoplanin, dan vancomycin. Hasil uji kepekaan antibiotik pada bakteri gram negatif yang memiliki sensitivitas di atas $70 \%$ adalah amikacin, gentamicin, imipenem, meropenem, dan piperacillin-tazobactam.

\section{Daftar Pustaka}

1. Soepandi PZ, Burhan E, Nawas A, Giriputro $\mathrm{S}$, Isbaniah F, Agustin H, et al. Perhimpunan dokter paru Indonesia. Pneumonia Komunitas. 2nd ed. Jakarta: Badan Penerbit FKUI, 2014

2. World Health Organization. The top 10 causes of death. 24 May 2018. [cited 3 Mar 2020] Available from: https://www.who.int/news-room/factsheets/detail/the-top-10-causes-of-death

3. Bocquenet $\mathrm{G}$, Chaiban T, Cook S, Escudero P, Franco A, Romo C, et al. A fair chance for every child. UNICEF 2016. [cited 10 Aug 2020] Available from: https://www.unicef.org/reports/state-worldschildren-2016

4. Child health | WHO | Regional Office for Africa. [cited 3 Mar 2020] Available from: https://www.afro.who.int/health-topics/childhealth.

5. Xu J, Murphy SL, Kochanek KD, Arias E. Mortality in the United States, 2014. NCHS Data Brief. 2015; 229: 1-8 [cited 10 Aug 2020] Available from: https://news.wttw.com/sites/default/files/arti cle/file-attachments/db267.pdf

6. World Health Organization. Pneumonia fact sheet. November 2016. [cited 10 Aug 2020] 
Available from: https://www.who.int/newsroom/fact-sheets/detail/pneumonia

7. Kemenkes RI. Riset kesehatan dasar tahun 2018. Kemenkes RI. Desember 2018. [cited 14 Feb 2021] Available from: http://labdata.litbang.kemkes.go.id/images/d ownload/laporan/RKD/2018/Laporan

_Nasional_RKD2018_FINAL.pdf

8. Cilloniz C, Loeches IM, Vidal CG, Jose AS, Torres A. Microbial etiology of pneumonia: epidemiology, diagnosis, and resistance patterns. Int $\mathrm{J}$ Mol Sci. 2016;17(12):2120.

9. World Health Organization. Antimicrobial resistance: global report on surveillance 2014. World Health Organization. April 2014. [cited 10 Aug 2020]Available from: https://www.who.int/drugresistance/docume nts/surveillancereport/en/

10. Holter JC, Müller F, Bjørang O, Samdal $\mathrm{HH}$, Marthinsen JB, Jenum PA, et al. Etiology of community-acquired pneumonia and diagnostic yields of microbiological methods: a 3-year prospective study in Norway. BMC Infect Dis. 2015;15(1):64. doi:10.1186/s12879015-0803-5.

11. Rahayu YD, Wahyono D, Mustofa. Evaluasi rasionalitas penggunaan antibiotik terhadap luaran pada pasien anak penderita pneumonia. Jurnal Manajemen dan Pelayanan Farmasi. 2014;4(4):264-70.

12. Guillamet CV, Vazquez R, Noe J, Micek ST, Kollef MH. A cohort study of bacteremic pneumonia: the importance of antibiotic resistance and appropriate initial therapy. Medicine (Baltimore). 2016; 95(35):4708.

13. Brad GF, Sabau I, Boia M, Marcovici T, Craciun A. Nilima $\mathrm{K}$, et al. Trends in bacterial pathogens of lower respiratory tract infections in children. Timisoara Medical Journal. 2011;61(3-4):193-8.

14. Weber M, Handy F. Action againts in children outline of a global action plan (GAPP). Jakarta. Buletin Jendela Epidemiologi. 2010;(3):11-5.

15. Asadullah, Isbandiyah, Sri AN. Pola bakteri penyebab pneumonia nosokomial di RS dr,
Soetomo Surabaya periode Januari 2011Maret 2012. Malang. Skripsi Fakultas Kedokteran Universitas Muhammadiyah Malang. 2015;11(1):64-7.

16. Farida H, Severin JA, Gasem MH, Keuter M, Van den Broek P, Hermans PWM, et al. Nasopharyngeal carriage of Klebsiella pneumoniae and other gram-negative bacilli in pneumonia-prone age groups in Semarang, Indonesia. J Clin Microbial. 2013;51(5):1614-6. doi:10.1128/JCM.0058913.

17. Dharmawan A, Karuniawati A, Sudarmono PP, Lestari DC, Rumende CM. Epithelial cells count and the ratio of leukocytes and epithelial cells as the criteria to determine qualified specimen for community-acquired pneumonia (CAP)-causing pathogens identification. The Indonesian Biomedical Journal. 2020;12(1):34-9. doi:10.18585/inabj.v12i1.873

18. Geller M, Nunes CP, Oliveira L, Nigri R. $S$. maltophilia pneumonia: a case report. Respiratory Medicine Case Reports. 2018; 24, 44-5. https://doi.org/10.1016/j.rmcr.2018.04.004

19. Kurniawan J, Erly, Semiarty R. Pola kepekaan bakteri penyebab pneumonia terhadap antibiotika di laboratorium mikrobiologi RSUP dr. M. Djamil Padang periode Januari sampai Desember 2011. Padang. Jurnal Kesehatan Andalas. 2015;4(2): 562-6

20. Weinstein MP, Lewis JS, Bobenchik AM, Campeau S, Cullen SK, Gallas MF, et al. Clinical and Laboratory Standard Institute. Performance standards for antimicrobial susceptibility testing. 29th ed. USA, 2019. p. $18-24$

21. Infectious Diseases Society of America. Management of adults with hospital-acquired and ventilator-associated pneumonia: 2016. clinical practice guidelines by the infectious diseases society of America and the American Thoracic Society. Infectious Diseases Society of America. Juli 2016. [cited 10 Jan 2021] Available from: https://www.idsociety.org/practiceguideline/hap vap/ 